\title{
LANDSLIDES TRIGGERED BY THE 2015 GORKHA, NEPAL EARTHQUAKE
}

\author{
Chong $\mathrm{Xu}^{1 *}$ \\ ${ }^{1}$ Institute of Geology, China Earthquake Administration, China - xc11111111@126.com
}

Commission III, ICWG III/Iva

KEY WORDS: Landslides, 2015 Gorkha earthquake, Inventory, Visual Interpretation, Landslide Density

\begin{abstract}
:
The 25 April 2015 Gorkha Mw 7.8 earthquake in central Nepal caused a large number of casualties and serious property losses, and also induced numerous landslides. Based on visual interpretation of high-resolution optical satellite images pre- and post-earthquake and field reconnaissance, we delineated 47,200 coseismic landslides with a total distribution extent more than $35,000 \mathrm{~km}^{2}$, which occupy a total area about $110 \mathrm{~km}^{2}$. On the basis of a scale relationship between landslide area (A) and volume $(\mathrm{V}), \mathrm{V}=1.3147 \times$ $\mathrm{A}^{1.2085}$, the total volume of the coseismic landslides is estimated to be about $9.64 \times 10^{8} \mathrm{~m}^{3}$. Calculation yields that the landslide number density, area density, and volume density are $1.32 \mathrm{~km}^{-2}, 0.31 \%$, and $0.027 \mathrm{~m}$, respectively. The spatial distribution of these landslides is consistent with that of the mainshock and aftershocks and the inferred causative fault, indicating the effect of the earthquake energy release on the pattern on coseismic landslides. This study provides a new, more detailed and objective inventory of the landslides triggered by the Gorkha earthquake, which would be significant for further study of genesis of coseismic landslides, hazard assessment and the long-term impact of the slope failure on the geological environment in the earthquake-scarred region.
\end{abstract}

\section{INTRODUCTION}

The 25 April 2015 Mw7.8 Gorkha (Nepal) earthquake caused at least 8800 deaths and tens of thousands of injuries(Hashash et al. 2015). This shock also triggered a large number of landslides and other secondary geological effects. The studies on inventory, mechanism, spatial distribution, and assessment of coseismic landslides are of great importance to mitigation of the potential subsequent hazards in the affected area (Harp et al. 2011; Xu et al. 2014a; Xu et al. 2014b; Xu et al. 2014c; Xu 2015; Xu et al. 2018). This work presents a new inventory of the landslides induced by the 2015 Gorkha event based on visual interpretation of high-resolution satellite images before and after the earthquake as well as verification at selected sites in the field, which is much more detailed and complete than previous work (Kargel et al. 2016; Gnyawali and Adhikari 2017 Martha et al. 2017; Roback et al. 2017). Our results show that the earthquake triggered at least 47,200 landslides, with a total occupation area of about $110 \mathrm{~km}^{2}$. These landslides are distributed in an ellipse with an area of about $35,700 \mathrm{~km}^{2}$. This inventor would be useful for further study of genesis of seismic landslides, impact of slope failure on the geological environment and hazard assessment in the affected region.

\section{GEOLOGIC SETTING}

The 2015 Gorkha Mw 7.8 earthquake occurred in the central Nepal Himalaya, where the Indian plate is underthrust beneath Asia (Powell and Conaghan 1973; Tapponnier et al. 1986; Royden et al. 2008). The present Himalayan orogen is dominated by three approximately parallel main thrusts with low dip angles $\left(\sim 10^{\circ}\right)$, i.e. the Main Frontal Thrust (MFT), the Main Boundary Thrust (MBT), and the Main Central Thrust (MCT), from south to north in the order of increasing ages of thrust initiations (Upreti 1999) (Figure 1). This fault system is one of the most active tectonics in the world. The 2015 Gorkha earthquake ruptured from east to west, and most aftershocks occurred in a rectangle area about $140 \mathrm{~km}$ in NWW-SEE direction and $50 \mathrm{~km}$ in NNE-SSW direction east to the mainshock epicentre. The seismogenic fault of this earthquake is considered to be the Main Frontal Thrust (MFT), but the rupture did not reach the ground surface, confined to depths 5$15 \mathrm{~km}$ below (Hubbard et al. 2016). Within 45 days of the main shock, a total of 553 aftershocks were recorded with Mw4.0+ (Adhikari et al. 2015). The largest aftershock occurred on May 12, with magnitude Mw7.3, which is located on the eastern boundary of the aftershock distribution area. It means the region between the Mw7.8 mainshock and the largest aftershock of Mw7.3 represents rupture extent of the seismogenic fault.

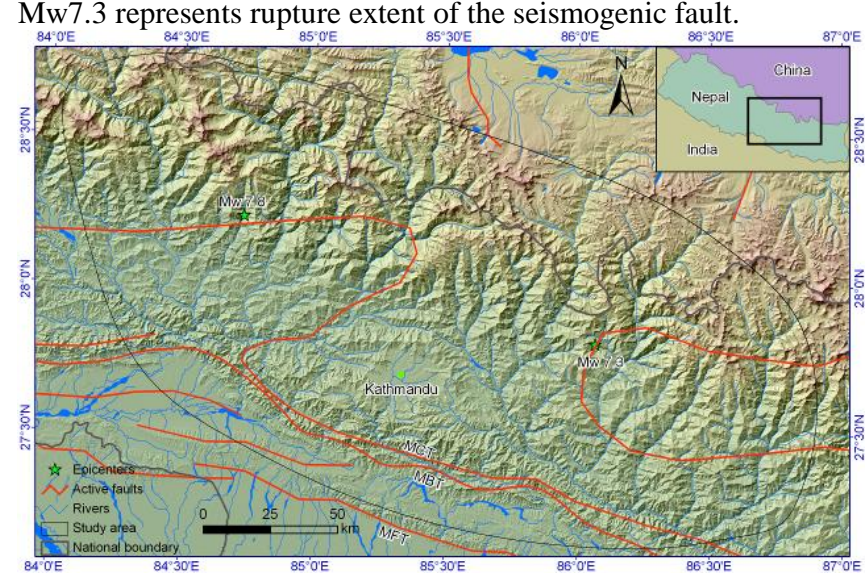

Figure 1. Map showing regional tectonic setting of the 2015

Gorkha earthquake. MFT, Main Frontal Thrust; MBT, Main Boundary Thrust; MCT, Main Central Thrust.

\section{DATA AND METHODS}

In this study, by combination of visual interpretation of highresolution satellite images and field investigations (Xu et al. 2015), a detailed landslide inventory for the Gorkha earthquake was prepared. The pre-earthquake satellite images, mainly from the Google Earth platform, and other high-resolution and good-

\footnotetext{
* Corresponding author
} 
quality satellite images of multiple sources fully cover the study area. The post-earthquake satellite images have two main sources, one is from China Centre for Resources Satellite Data and Application, including GF1, GF2, ZY02C, ZY3, and CB04 (Figure 2); the other is true colour or panchromatic images from Google Earth platform, such as CNES/Astrium and DigitalGlobe (Figure 3). The coverage of the two sources of satellite images almost covers the entire landslide distribution area; only about $1 \%\left(\sim 350 \mathrm{~km}^{2}\right)$ of the region near the boundary of the landslide distribution area is beyond the coverage. The Landsat 8 image of $15 \mathrm{~m}$ resolution was supplemented to this $1 \%$ of the landslide distribution area. In addition, detailed field investigations were carried on along the Pasang Lhamu Highway that connects Kathmandu, Nepal and Gyirong County and the Araniko Highway that links Kathmandu, Nepal and Nielamu County, China for tens of days by cars or by walk $(\mathrm{Xu}$ et al. 2016a).

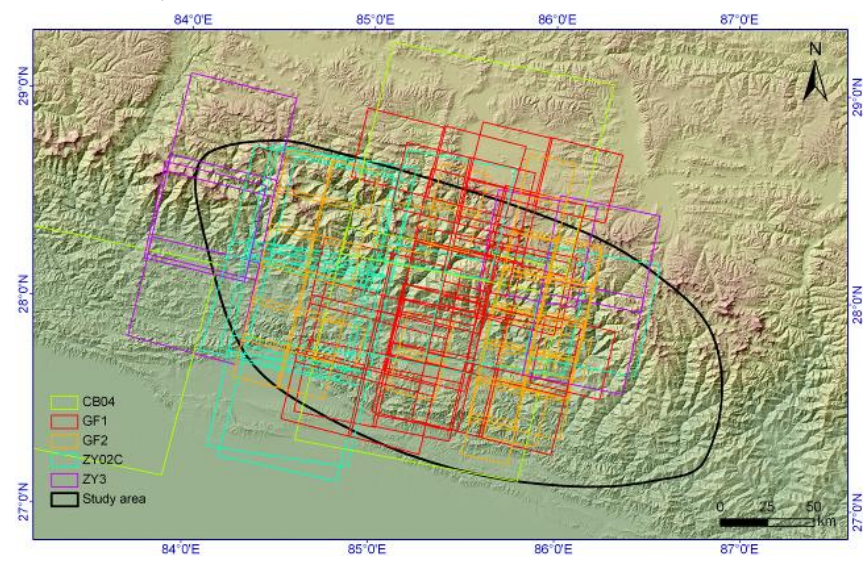

Figure 2. Coverage of pre-earthquake satellite images by China

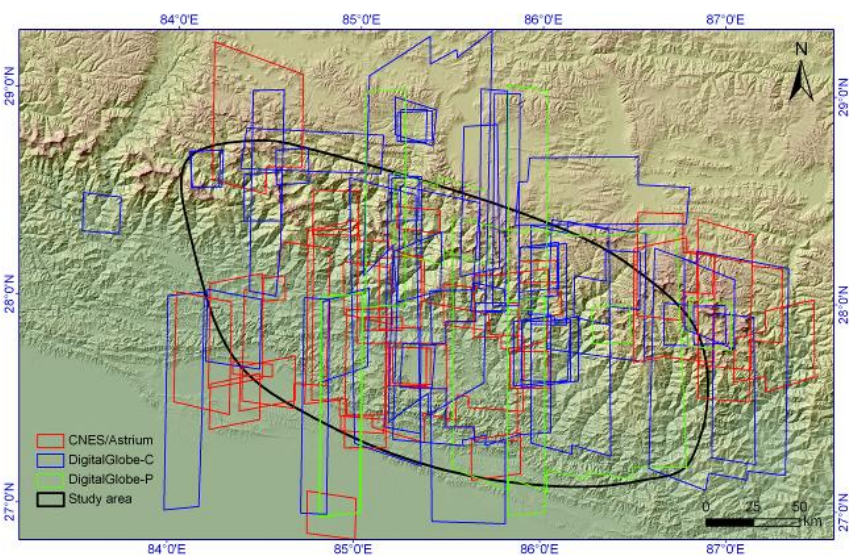

Figure 3. Coverage of pre-earthquake satellite images from Google Earth

\section{RESULTS}

\subsection{Comparison of satellite images and filed photos}

Figure 4 shows two groups of comparison of satellite images from the Google Earth platform and field photos of coseismic landslides to illustrate the high-resolution, good-quality, and excellent capacity of detecting coseismic landslides on highresolution satellite images, which permit to map the locations and boundaries of coseismic landslides correctly and conveniently(Xu et al. 2017).

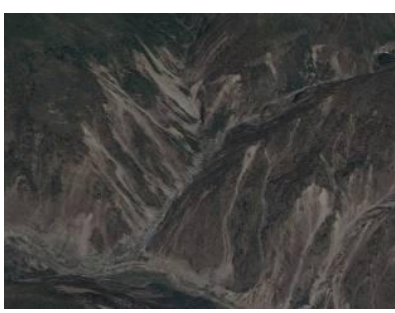

(a)

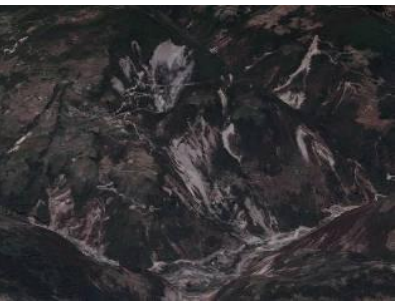

(c)

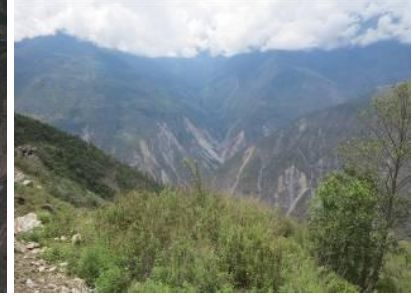

(b)

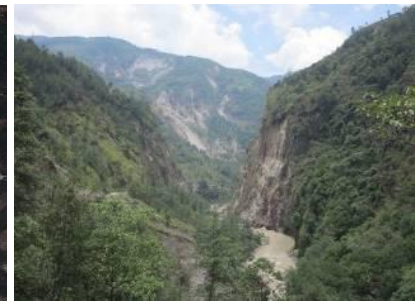

(d)
Figure 4. Comparisons of coseismic landslides on satellite images and field photos. (a) Satellite image of 3 May 2015 from

Google Earth platform. (b) Field photo of 15 June 2015. (c)

Satellite image of 25 May 2015 from Google Earth platform. (d) Field photo of 14 June 2015. (a) and (b), (c) and (d) show the same scenes at the Pasang Lhamu Highway and the Araniko Highway, respectively.

\subsection{Typical landslides}

4.2.1 Prok landslide: This landslide is located at $28.555^{\circ} \mathrm{N}$, $84.793^{\circ} \mathrm{E}$, about 5 kilometres downstream to the China/Nepal border, with elevation from $3170 \mathrm{~m}$ to $2460 \mathrm{~m}$ (Figure 5). It has dammed a river and resulted in a lake near the Prok village. The thoroughly destroyed and erased of the trees on the slope shows it is a disruptive landslide. Comparison between the preearthquake (Fig. 1a) and post-earthquake images (Figs. 1b, 1c and 1d) allowed us to delineate this landslide objectively. The volume of the landslide was estimated to be $3000,000 \mathrm{~m}^{3}$.

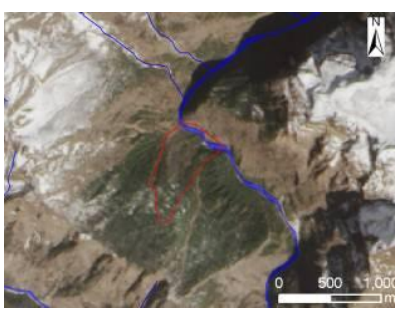

(a)

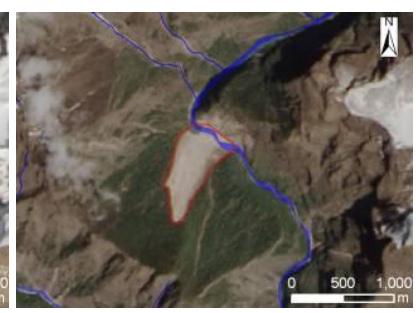

(b)
Figure 5. Satellite images show the Prok landslide dam. (a) Landsat 8 image taken on March 13, 2015, 15 m resolution; (b) Landsat 8 image taken on April 30, 2015, 15 m resolution 
4.2.2 Pisang landslide: This landslide was lies about $2 \mathrm{~km}$ upstream of the Lower Pisang village, Manang District in the Gandaki zone. It is a deep-seated rotational landslide that blocked majority of the river (Figure 6). Landsliding occurred on a gentle slope with angle about $15^{\circ}$. The river bank of the landslide front edge is rather steep. The trees on the landslide body is moderately damaged and back-declined, implying a rotational, deep-seated landslide. Actually it was not triggered by the main shock, because it is absent on the ZY3 satellite image of April 27, 2015 (Figure 6a), instead induced by an aftershock or a heavy rainfall (Figure 6b).

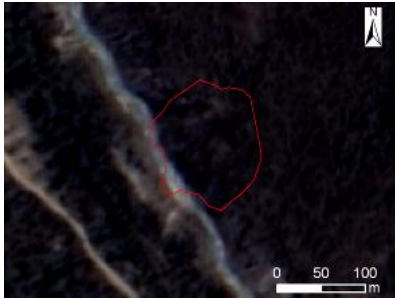

(a)

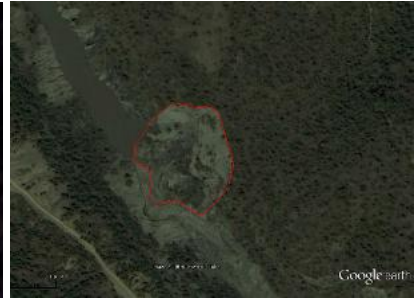

(b)
Figure 6. The Pisang landslide. (a) ZY3 satellite image taken on April 27, 2015; (b) Digital Globe satellite image from Google Earth taken on May 21, 2015

4.2.3 Langtang landslide: It is the largest landslide triggered by the Gorkha earthquake, which buried the Langtang village and killed about 400 victims (Figure 7). Its volume is estimated to be more than $10,000,000 \mathrm{~m}^{3}$. The landslide is composed of debris materials, ice and snow. The comparison of preearthquake satellite image (Figure 6a) from Google Earth platform and post-earthquake GF1 (China) satellite image (Figure $7 b$ ) reveals the extent of the landslide damage. The Langtang village was completely destroyed by the large, wet, debris- and ice-laden avalanches.

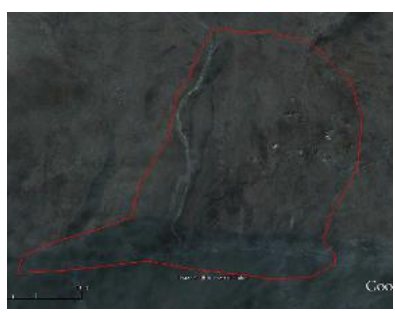

(a)

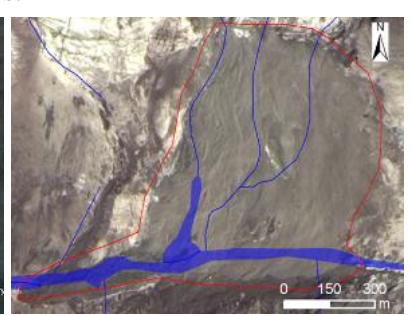

(b)
Figure 7. The Langtang landslide. (a) Satellite image from Google Earth taken on January 22, 2015; (b) GF1 (China) satellite image on May 10, 2015

\subsection{Landslide inventory}

Statistics show that at least 47,200 landslides were triggered by the Gorkha earthquake, which are distributed in an oval area about $35,700 \mathrm{~km}^{2}$ with its long axis in NWW-SEE direction, which is consistent with the seismogenic fault and distribution of aftershocks. The total occupation area of these landslides is about $110 \mathrm{~km}^{2}$ (Figure 8). According to the landslide power law relationship of "area (A) - volume $(\mathrm{V})$ ", $\mathrm{V}=1.3147 \times \mathrm{A}^{1.2085}$ (Xu et al. 2016b), the total volume of these landslides is estimated to be about 964 million cubic meters. In the landslide distribution area, the landslide point density is $47200 / 35,664 \mathrm{~km}^{2}=1.32 \mathrm{~km}^{-2}$, the landslide area percentage is $110.46 \mathrm{~km}^{2} / 35,664 \mathrm{~km}^{2} \times 100 \%=0.31 \%$, and the landslide volume density is $964 \times 10^{6} \mathrm{~m}^{3} / 35,664 \mathrm{~km}^{2}=0.027 \mathrm{~m}$. The largest landslide has an area more than $600,000 \mathrm{~m}^{2}$, and the smallest one only $1 \sim 2 \mathrm{~m}^{2}$. Of the 47,200 coseismic landslides, 22 landslides have area exceeding $100,000 \mathrm{~m}^{2}, 2,042$ between $10,000 \mathrm{~m}^{2}$ and $100,000 \mathrm{~m}^{2}, 18,359$ between $1,000 \mathrm{~m}^{2}$ and $10,000 \mathrm{~m}^{2}, 24,109$ between $100 \mathrm{~m}^{2}$ and $1,000 \mathrm{~m}^{2}$, and the remaining 2,668 less than $100 \mathrm{~m}^{2}$.

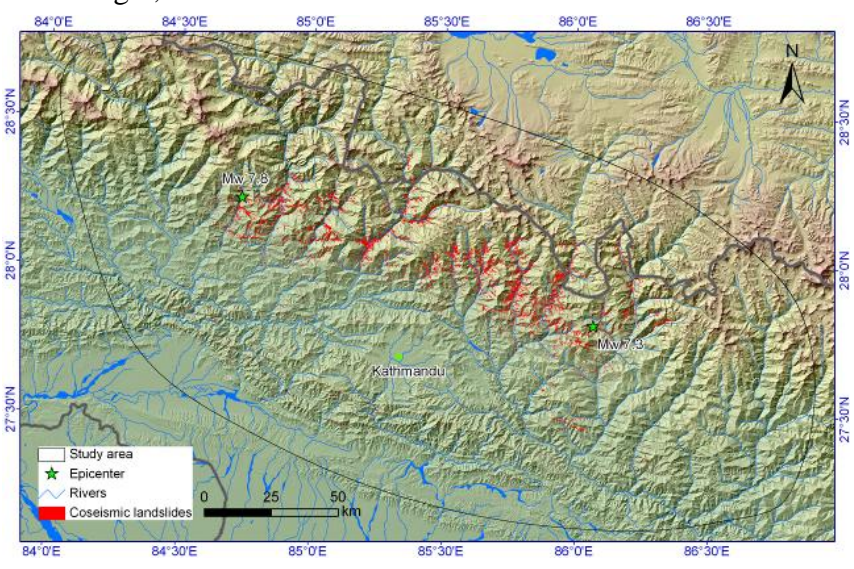

Figure 8. Spatial distribution of landslides triggered by the Gorkha earthquake

\subsection{Landslide density}

This work took $1 \mathrm{~km}$ as the search radius and selected the Kernel function type to construct the coseismic landslide point density distribution map with resolution of the grid set to $100 \mathrm{~m}$ (Figure 9). The maximum landslide density is as high as $132.2 \mathrm{~km}^{-2}$. The area was divided into nine types based on classification of landslide density, which are $0,0-1 \mathrm{~km}^{-2}, 1-2$ $\mathrm{km}^{-2}, 2-5 \mathrm{~km}^{-2}, 5-10 \mathrm{~km}^{-2}, 10-20 \mathrm{~km}^{-2}, 20-50 \mathrm{~km}^{-2}, 50-100 \mathrm{~km}^{-2}$, and $100-132.2 \mathrm{~km}^{-2}$ (Figure 6). The high landslide density area is located between the Mw7.8 mainshock and the Mw7.3 aftershock. The length and width of the area are about $170 \mathrm{~km}$ and $40 \mathrm{~km}$, respectively. These data can help us to understand quantitatively the development and spatial distribution of Gorkha earthquake-triggered landslides.

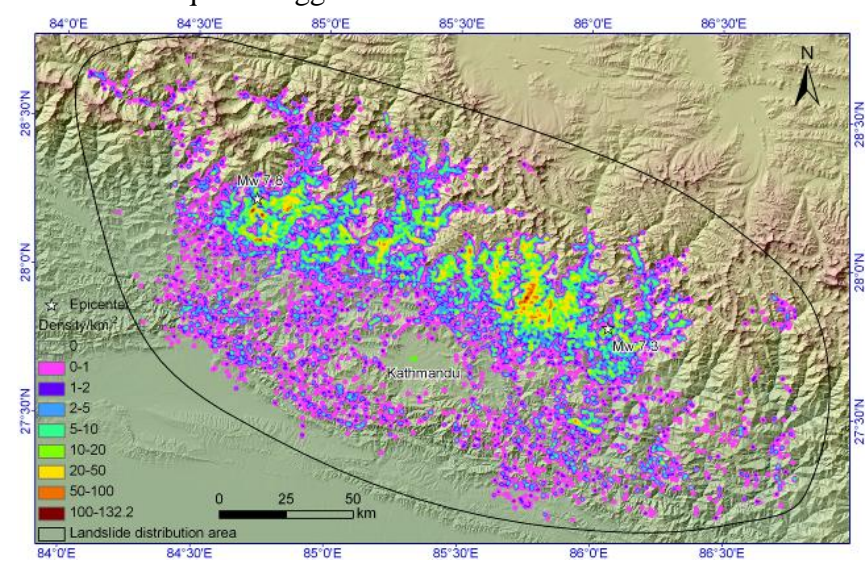

Figure 9. Map showing density of landslides triggered by the 2015 Gorkha earthquake

\section{CONCLUSIONS}

This study established a detailed, objective, and completed inventory of landslides triggered by the April 25, 2015 Gorkha, Nepal Mw7.8 earthquake using remote sensing and field 
observations. The results show that the earthquake triggered at least 47,200 landslides which occupy a total area about $110 \mathrm{~km}^{2}$ The total volume of the landslides is estimated to be 964 million cubic meters. These landslides are distributed in an oval area of $35,700 \mathrm{~km}^{2}$ with its long axis in the NWW-SEE direction. Statistics show the landslide density, area percentage and volume density are $1.32 \mathrm{~km}^{-2}, 0.31 \%$ and $0.027 \mathrm{~m}$, respectively. The landslide density distribution map was also prepared, showing the maximum density of coseismic landslides is as high as $132.2 \mathrm{~km}^{-2}$. This study provides a detailed landslide inventory for the 2015 Gorkha, Nepal earthquake, which would be useful for further analyzing the genesis of seismic landslides, long-term impact of slope failure on the environment and hazard assessment of in the affected area.

\section{ACKNOWLEDGEMENTS}

This study was supported by the major international (regional) joint research project (41661144037) from the National Natural Science Foundation of China (NSFC) and the International Centre for Integrated Mountain Development (ICIMOD).

\section{REFERENCES}

Adhikari, L.B., Gautam, U.P., Koirala, B.P., Bhattarai, M., Kandel, T., Gupta, R.M., Timsina, C., Maharjan, N., Maharjan, K., Dahal, T., Hoste-Colomer, R., Cano, Y., Dandine, M. Guilhem, A., Merrer, S., Roudil, P., and Bollinger, L., 2015. The aftershock sequence of the 2015 April 25 Gorkha-Nepal earthquake. Geophysical Journal International, 203(3), pp. 2119-2124.

Gnyawali, K.R. and Adhikari, B.R., 2017. Spatial relations of earthquake induced landslides triggered by 2015 Gorkha earthquake $\mathrm{Mw}=7.8$. Workshop on World Landslide Forum, pp. 85-93.

Harp, E.L., Keefer, D.K., Sato, H.P., and Yagi, H., 2011. Landslide inventories: The essential part of seismic landslide hazard analyses. Engineering Geology, 122(1-2), pp. 9-21.

Hashash, Y.M.A., Tiwari, B., Moss, R.E.S., Asimaki, D., Clahan, K.B., Kieffer, D.S., Dreger, D.S., Macdonald, A., Madugo, C.M., Mason, H.B., Pehlivan, M., Rayamajhi, D., Acharya, I., and Adhikari, B., 2015. Geotechnical field reconnaissance: Gorkha (Nepal) earthquake of April 25, 2015 and related shaking sequence. Geotechnical Extreme Event Reconnaisance GEER Association Report No. GEER-040, https://works.bepress.com/rmoss/47: 250 pages.

Hubbard, J., Almeida, R., Foster, A., Sapkota, S.N., Bürgi, P., and Tapponnier, P., 2016. Structural segmentation controlled the $2015 \mathrm{Mw} 7.8$ Gorkha earthquake rupture in Nepal. Geology, 44(8), pp. 639-642.

Kargel, J.S., Leonard, G.J., Shugar, D.H., Haritashya, U.K., Bevington, A., Fielding, E.J., Fujita, K., Geertsema, M., Miles, E.S., Steiner, J., Anderson, E., Bajracharya, S., Bawden, G.W., Breashears, D.F., Byers, A., Collins, B., Dhital, M.R., Donnellan, A., Evans, T.L., Geai, M.L., Glasscoe, M.T., Green, D., Gurung, D.R., Heijenk, R., Hilborn, A., Hudnut, K., Huyck, C., Immerzeel, W.W., Jiang, L., Jibson, R., Kääb, A., Khanal, N.R., Kirschbaum, D., Kraaijenbrink, P.D.A., Lamsal, D., Liu, S., Lv, M., McKinney, D., Nahirnick, N.K., Nan, Z., Ojha, S., Olsenholler, J., Painter, T.H., Pleasants, M., Pratima, K.C., Qi, Y., Raup, B.H., Regmi, D., Rounce, D.R., Sakai, A., Shangguan,
D., Shea, J.M., Shrestha, A.B., Shukla, A., Stumm, D., van der Kooij, M., Voss, K., Wang, X., Weihs, B., Wolfe, D., Wu, L., Yao, X., Yoder, M.R., and Young, N., 2016. Geomorphic and geologic controls of geohazards induced by Nepal's 2015 Gorkha earthquake. Science, 351(6269), aac8353.

Martha, T.R., Roy, P., Mazumdar, R., Govindharaj, K.B., and Kumar, K.V., 2017. Spatial characteristics of landslides triggered by the $2015 \mathrm{Mw} 7.8$ (Gorkha) and Mw 7.3 (Dolakha) earthquakes in Nepal. Landslides, 14(2), pp. 697-704.

Powell, C.M. and Conaghan, P.J., 1973. Plate tectonics and the Himalayas. Earth and Planetary Science Letters, 20(1), pp. 112.

Roback, K., Clark, M.K., West, A.J., Zekkos, D., Li, G., Gallen, S.F., Champlain, D., and Godt, J.W., 2017. Map data of landslides triggered by the 25 April $2015 \mathrm{Mw} 7.8$ Gorkha, Nepal earthquake. U.S. Geological Survey data release.

Royden, L.H., Burchfiel, B.C., and van der Hilst, R.D., 2008. The geological evolution of the Tibetan Plateau. Science, 321(5892), pp. 1054-1058.

Tapponnier, P., Peltzer, G., and Armijo, R., 1986. On the mechanics of the collision between India and Asia. Geological Society, London, Special Publications, 19(1), pp. 113-157.

Upreti, B.N., 1999. An overview of the stratigraphy and tectonics of the Nepal Himalaya. Journal of Asian Earth Sciences, 17(5-6), pp. 577-606.

Xu, C., 2015. Preparation of earthquake-triggered landslide inventory maps using remote sensing and GIS technologies: Principles and case studies. Geoscience Frontiers, 6(6), pp. 825-836.

Xu, C., Xu, X., Yao, X., and Dai, F., 2014a. Three (nearly) complete inventories of landslides triggered by the May 12, 2008 Wenchuan Mw 7.9 earthquake of China and their spatial distribution statistical analysis. Landslides, 11(3), pp. 441-461.

Xu, C., Shyu, J.B.H., and Xu, X., 2014b. Landslides triggered by the 12 January 2010 Port-au-Prince, Haiti, Mw $=7.0$ earthquake: visual interpretation, inventory compiling, and spatial distribution statistical analysis. Natural Hazards and Earth System Sciences, 14(7), pp. 1789-1818.

Xu, C., Xu, X., Shyu, J.B.H., Zheng, W., and Min, W., 2014c. Landslides triggered by the 22 July 2013 Minxian-Zhangxian, China, Mw 5.9 earthquake: Inventory compiling and spatial distribution analysis. Journal of Asian Earth Sciences, 92, pp. 125-142.

Xu, C., Xu, X., and Shyu, J.B.H., 2015. Database and spatial distribution of landslides triggered by the Lushan, China Mw 6.6 earthquake of 20 April 2013. Geomorphology, 248, pp. 7792.

Xu, C., Xu, X., Tian, Y., Shen, L., Yao, Q., Huang, X., Ma, J., Chen, X., and Ma, S., 2016a. Two comparable earthquakes produced greatly different coseismic landslides: The 2015 Gorkha, Nepal and 2008 Wenchuan, China events. Journal of Earth Science, 27(6), pp. 1008-1015. 
Xu, C., Xu, X., Shen, L., Yao, Q., Tan, X., Kang, W., Ma, S., Wu, X., Cai, J., Gao, M., and Li, K., 2016b. Optimized volume models of earthquake-triggered landslides. Scientific Reports, 6, 29797.

Xu, C., Tian, Y., Zhou, B., Ran, H., and Lyu, G., 2017. Landslide damage along Araniko Highway and Pasang Lhamu Highway and regional assessment of landslide hazard related to the Gorkha, Nepal earthquake of 25 April 2015. Geoenvironmental Disasters, 4(1), 14.

Xu, C., Ma, S., Tan, Z., Xie, C., Toda, S., and Huang, X., 2018. Landslides triggered by the $2016 \mathrm{Mj} 7.3$ Kumamoto, Japan, earthquake. Landslides, 15(3), pp. 551-564. 